\title{
Peningkatan Hasil Belajar Kognitif Biologi Melalui Problem Based Learning Pada Siswa Kelas X SMA Negeri 1 Bulu Sukoharjo
}

\author{
Winda Nirwana Anggraini ${ }^{1}$, Agus Purwanto ${ }^{2}$, Anwari Adi Nugroho ${ }^{3}$ \\ 1,2,3 Program Studi Pendidikan Biologi, Universitas Veteran Bangun Nusantara Sukoharjo. \\ Jl. Letjend Sujono Humardani Street, No.1, Gadingan, Jombor, Bendosari, Sukoharjo, Jawa Tengah 57521 \\ Coressponding Author E-mail: \\ ${ }^{1}$ windanirwana643@gmail.com \\ Received: January $10^{\text {th }}, 2020$ \\ Accepted: January $28^{\text {th }}, 2020$ \\ Online Published: January 31st, 2020

\begin{abstract}
Abstrak
Penelitian ini bertujuan untuk meningkatkan hasil belajar kognitif biologi melalui model Problem Based Learning pada siswa kelas X SMA Negeri 1 Bulu Kabupaten Sukoharjo Tahun Pelajaran 2018/2019. Jenis penelitian ini adalah PTK yang terdiri dari 2 siklus. Tiap siklus terdiri dari perencanaan, pelaksanaan, observasi dan refleksi. Teknik pengumpulan data dengan menggunakan dokumentasi, tes dan lembar observasi kegiatan pembelajaran. Data dan sumber data berasal dari siswa yang dijadikan subjek penelitian dan guru mata pelajaran biologi. Teknik analisis data dengan menggunakan deskriptif komparatif. Hasil penelitian menyatakan bahwa hasil siklus I ketuntasan hasil belajar kognitif sebesar 67\% (19 siswa tuntas KKM). Hasil tersebut belum memenuhi indikator keberhasilan sebesar $80 \%$ (22 siswa tuntas KKM). Pada siklus II mengalami peningkatan ketuntasan hasil belajar kognitif 85\% (24 siswa tuntas KKM) sudah memenuhi indikator keberhasilan yaitu $80 \%$. Sehingga dapat disimpulkan bahwa model PBL dapat meningkatkan hasil belajar kognitif biologi.
\end{abstract}

Kata kunci: Hasil Belajar, Kognitif, Problem Based Learning

\begin{abstract}
This study aims to improve cognitive learning outcomes in biology through Problem Based Learning models in class X students of SMA Negeri 1 Bulu, Sukoharjo Regency in the 2018/2019 Academic Year. This type of research is a CAR consisting of two cycles. Each cycle consists of planning, implementing, observing and reflecting. Data collection techniques using documentation, tests and observation sheets of learning activities. Data and data sources come from students who are subjected to research and biology subject teachers. Data analysis techniques using comparative descriptive. The results of the study stated that the results of the first cycle of completeness cognitive learning outcomes by 67\% (19 students completed KKM). These results do not meet the success indicator of $80 \%$ (22 students complete KKM). In cycle II experienced 85\% completeness of cognitive learning outcomes (24 students completed KKM) had met the success indicator that is $80 \%$. So it can be concluded that the PBL model can improve biology cognitive learning outcomes.
\end{abstract}

Keywords: Learning Outcomes, Cognitive, Problem Based Learning

How to cite this article :

Anggraini, W. N, Purwanto, A., \& Nugroho, A. A. (2020). Peningkatan Hasil Belajar Kognitif Biologi Melalui Problem Based Learning Pada Siswa Kelas X SMA Negeri 1 Bulu Sukoharjo. IJIS Edu : Indonesian Journal of Integrated Science Education, 2(1), 55-62. doi:http://dx.doi.org/10.29300/ijisedu.v2i1.2864 


\section{PENDAHULUAN}

Pembelajaran biologi ideal seharusnya sesuai dengan hakikatnya sebagai sains, yaitu: proses, produk, sikap. Pembelajaran biologi memungkinkan peserta didik melakukan serangkaian keterampilan proses sains mulai dari mengamati, mengelompokkan (klasifikasi), mengukur, menghitung, meramalkan, mengkomunikasikan, mengajukan pertanyaan (bertanya), menyimpulkan, mengontrol variabel, merumuskan masalah, membuat hipotesis, merancang penyelidikan, melakukan penyelidikan/percobaan. Setelah melakukan serangkaian keterampilan proses, siswa akan mengkonstruk konsep-konsep materi biologi. Selama melakukan serangkaian proses ilmiah, diharapkan dapat dikembangkan sikap ilmiah seperti: jujur, obyektif, teliti, menghargai orang lain, disiplin, dll. Prinsip pembelajaran biologi sangat relevan dengan paham konstruktivistik, dimana belajar merupakan proses pengkonstruksian konsep melalui pengalaman oleh siswa, bukan pemberian konsep oleh guru (Sudarisman, 2015).

Pembelajaran biologi seharusnya dirancang untuk memberikan kesempatan siswa menemukan fakta, membangun konsep, dan menemukan nilai baru. Siswa harus diposisikan sebagai subjek belajar dalam kegiatan pembelajaran. Siswa bukan diposisikan sebagai penonton kerja ilmiah guru, tetapi diposisikan sebagai pelaku kerja ilmiah (Sugiharto, 2011).

Pembelajaran biologi berdasarkan kurikulum 2013 adalah melalui pendekatan saintifik dalam seluruh proses pembelajaran. Pendidikan saintifik dalam kurikulum 2013 dikenal adanya kegiatan mengamati, menanya, menalar, mengasosiasi dan mengkomunikasikan (membangun jejaring sosial), sehingga dalam pembelajaran kurikulum 2013, guru tidak langsung menjelaskan materi pelajaran, tetapi siswa yang aktif dalam proses pembelajaran dan guru hanya bertindak sebagai fasilitator (Gusti, Suyanto \& Ratnawati, 2017).

Namun pada kenyataannya pembelajaran Biologi di SMA Negeri 1 Bulu belum sesuai dengan pembelajaran biologi ideal berdasarkan kurikulum 2013. Hasil observasi terhadap hasil belajar kognitif di kelas X IPA 3 dengan KKM 70, paling rendah jika dibandingkan dengan 3 kelas X IPA yang lain. Presentase ketuntasan kelas X IPA 1 69\% dari 29 siswa, berarti 20 siswa tuntas KKM. Pada kelas X IPA 2 60\% dari 28 siswa, berarti 17 siswa tuntas KKM.
Pada kelas X IPA 3 43\% dari 28 siswa, berarti 12 siswa tuntas KKM. Pada kelas X IPA 4 58\% dari 29 siswa, berarti 17 siswa tuntas KKM.

Berdasarkan permasalahan di kelas X IPA 3 maka pokok permasalahannya adalah hasil belajar biologi yang rendah dan akar permasalahannya pada pembelajaran biologi yang tidak sesuai dengan kurikulum 2013. Sehingga solusinya adalah Penelitian Tindakan Kelas dengan menggunakan model PBL.

Model PBL mengakomodasi tuntutan kurikulum 2013, selain itu model PBL ini dipilih karena merupakan pembelajaran yang penyampaiannya dilakukan dengan cara menyajikan suatu permasalahan, mengajukan pertanyaan-pertanyaan, memfasilitasi penyelidikan, dan membuka dialog. Model PBL dapat meningkatkan mental activities siswa, dalam PBL menuntut siswa untuk aktif menanggapi, mengingat, memecahkan persoalan, menganalisis dan membuat keputusan (Ulfah, Fatmah, \& Herlanti, 2015).

PBL adalah model pembelajaran yang dapat mendorong siswa untuk aktif berpikir lebih dalam ketika siswa mempelajari sesuatu atau ketika diberikan suatu masalah. Proses pembelajaran sebaiknya dapat menyajikan fenomena-fenomena yang terjadi di sekitar siswa, masalah nyata dan bermakna yang menantang siswa untuk memecahkannya (Putra \& Bektiarso, 2017).

PBL merupakan salah satu model pembelajaran yang menuntut aktivitas mental siswa untuk memahami suatu konsep pembelajaran melalui situasi dan masalah yang disajikan pada awal pembelajaran dengan tujuan untuk melatih siswa menyelesaikan masalah dengan menggunakan pendekatan pemecahan masalah. Pemecahan masalah berhubungan dengan kemampuan berpikir kritis karena berpikir kritis merupakan suatu proses yang digunakan ketika mendatangkan (memunculkan) suatu ide baru dengan menggabungkan ide-ide yang sebelumnya dilakukan (Kono, Mamu \& Tangge, 2016).

PBL adalah salah satu model pembelajaran yang dapat menyediakan lingkungan belajar yang mendukung berpikir kritis. PBL didasarkan pada situasi bermasalah yang membingungkan. Permasalahan tersebut akan membangkitkan rasa ingin tahu siswa, sehingga siswa akan tertarik untuk menyelidiki permasalahan. Pada saat siswa melakukan penyelidikan, maka siswa menggunakan tahapan berpikir kritis untuk menyelidiki masalah, 
menganalisa berdasarkan bukti dan mengambil keputusan berdasarkan hasil penyelidikan, hal tersebut dapat meningkatkan aktivitas mental siswa (Nafiah \& Suyanto, 2014).

Keunggulan PBL diantaranya adalah siswa akan terbiasa menghadapi masalah dan merasa tertantang untuk menyelesaikan masalah, memupuk solidaritas sosial, makin mengakrabkan guru kepada siswa, membiasakan siswa dalam menerapkan metode eksperimen karena ada kemungkinan suatu masalah harus diselesaikan siswa melalui eksperimen (Sari, Budijanto \& Amirrudin, 2017).

\section{METODE}

Jenis Penelitian ini adalah Penelitian Tindakan Kelas (PTK). Penelitian ini terdiri dari 2 siklus, dimana dalam satu siklus tindakan meliputi, perencanaan, pelaksanaan, observasi dan refleksi. Berikut adalah skema penelitian tindakan kelas:

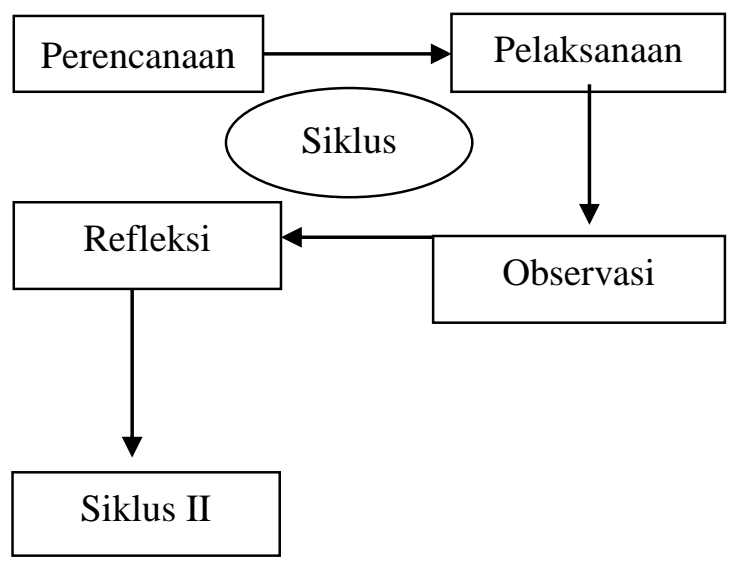

Gambar 1. Skema Penelitian Tindakan Kelas

Kegiatan penelitian dilaksanakan pada semester genap tahun pelajaran 2018/2019 dari April sampai minggu ke dua Mei pada siswa kelas X IPA 3 SMA Negeri 1 Bulu Kabupaten Sukoharjo, dengan jumlah siswa 28 yaitu 12 perempuan dan 6 laki-laki. Sumber data pada penelitian ini diperoleh dari dokumen mengenai data siswa dan diperoleh data hasil kognitif dari tes. Prosedur pengumpulan data pada penelitian ini dengan menggunakan dokumentasi, tes dan lembar observasi. Instrumen penelitian berupa Silabus, RPP (Rencana Pelaksaan Pembelajaran), dan butir 4 soal uraian untuk siklus I dan 6 soal uraian untuk siklus II. Teknik analisis data pada penelitian ini dengan menggunakan deskriptif komparatif. Indikator keberhasilan pada penelitian ini adalah $80 \%$ (22 siswa tuntas $\mathrm{KKM})$.

\section{HASIL DAN PEMBAHASAN}

Penelitian Tindakan Kelas ini dilaksanakan di SMA Negeri 1 Bulu Sukoharjo pada bulan April 2019.

\section{SIKLUS I}

Siklus I dilaksanakan pada Selasa, 23 April 2019. Dengan alokasi waktu 3 × 45 menit pada jam ke 5 - $6(10.15-11.40)$ dan jam ke 7 (12.15 - 13.05). Materi yang disampaikan adalah keseimbangan lingkungan dan pencemaran lingkungan. Proses pembelajaran dilakukan oleh guru biologi dan peneliti menggunakan dua observer sebagai pengamat dalam proses pembelajaran. Kegiatan pembelajaran siklus I dapat dijelaskan sebagai berikut:

Kegiatan yang pertama adalah pendahuluan, dilakukan selama 15 menit dari jam 10.15 - 10.30. Pada kegiatan pendahuluan sebagian siswa sudah siap dalam kegiatan pembelajaran. Hal ini terlihat saat guru menyampaikan salam pembuka, sebagian siswa menjawab salam guru. Pada saat guru memberikan pertanyaan, sebagian siswa aktif menjawab pertanyaan guru. Begitu pula saat guru menyampaikan langkah-langkah $P B L$, sebagian siswa memperhatikan guru.

\section{Tahap mengorientasi peserta didik terhadap masalah}

Tahap ini dilakukan selama 10 menit dari jam 10.30 -10.40. Pada saat guru memberikan motivasi atau rangsangan kepada siswa untuk memusatkan perhatian pada topik materi perubahan lingkungan, sebagian siswa memperhatikan motivasi yang disampaikan guru.

Pada saat guru mengarahkan siswa untuk menulis poin-poin permasalahan hasil diskusi, sebagian anggota kelompok menuliskan poinpoin permasalahan hasil diskusi. Materi diskusi tiap kelompok berbeda. Kelompok 1: Sungai Cilimaya Karawang Tercemar, Diduga dari Limbah Pabrik di Subang. Kelompk 2: Polusi Udara Akibat Kebakaran Hutan Masih Selimuti Dumai. Kelompok 3: Pembanguan Gudang Sabun di Sidimpuan diprotes Warga. Kelompok 4: Warga di Sleman Tuntut Pembubaran Kandang Babi. Kelompok 5 : Eutrofikasi Penyebab Kematian Massal Ikan.

Tahap mengorganisasi siswa untuk belajar

Tahap ini dilakukan selama 10 menit dari jam 10.40 - 10.50. Pada saat guru mengarahkan 
siswa untuk mencari dasar teori berdasarkan rumusan masalah, 1 siswa dari anggota kelompok menuliskan dasar teori berdasarkan rumusan masalah yang ditemukan.

\section{Tahap mendukung kelompok investigasi}

Tahap ini dilakukan selama 15 menit dari jam 10.50 - jam 11.05. Pada saat guru membimbing siswa dalam kelompok untuk berdiskusi, semua siswa berdiskusi untuk mencari data informasi mengenai pencemaran lingkungan yang terjadi di sekitarnya dan berusaha untuk menemukan solusi yang tepat.

Tahap mengembangkan dan menyajikan artefak dan memamerkannya

Tahap ini dilakukan selama 35 menit dari jam 11.05 - jam 11.40. Pada saat guru mengarahkan siswa untuk membuat mind mapping, sebagian siswa memahami dan tidak kesulitan dalam menuangkan gagasan maupun penyelesaian masalah dalam bentuk mind mapping. Dalam penyelesaian mind mapping siswa hanya membutuhkan waktu sekitar 25 menit.

Tahap menganalisis dan mengevaluasi proses pemecahan masalah

Tahap ini dilakukan selama 35 menit dari jam 12.15 - jam 12.50. Pada saat guru mengarahkan siswa untuk memverifikasi hasil diskusi dengan literatur dan mengkonsultasikan kepada guru, sebagian kelompok mengkonsultasikan hasil diskusi kepada guru.

Pada saat kegiatan presentasi, siswa interaktif terutama kelompok 2, 4 dan 5 mereka memperhatikan saat kelompok lainnya melakukan presentasi.

Pada akhir pembelajaran siklus I yaitu kegiatan penutup, dilakukan selama 15 menit dari jam 12.50 - 13.05. Siswa mengerjakan soal post test selama 10 menit.

Setelah menerapkan model PBL dilakukan evaluasi untuk mengetahui hasil belajar kognitif siswa. Dari hasil yang diperoleh pada siklus I dapat diketahui bahwa siswa yang memperoleh nilai 70 dan dinyatakan tuntas hanya ada 19 siswa (67\%) dan yang belum tuntas ada 9 siswa (23\%), hal ini menunjukkan bahwa hasil ketuntaan belajar belum memenuhi indikator keberhasilan yaitu $80 \%$, dapat dilihat pada gambar 2:

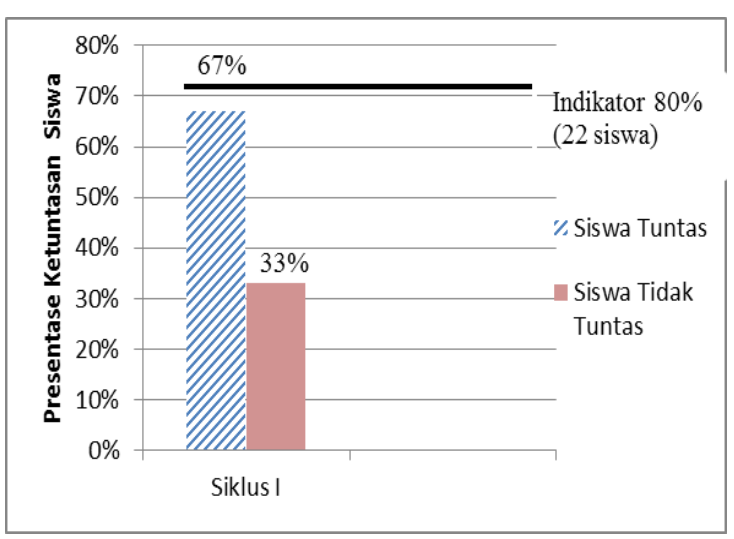

Gambar 2. Histogram Ketuntasan Siswa Siklus I

Karena siklus I belum mencapai indikator keberhasilan, maka guru dan peneliti melakukan perbaikan guna mengoptimalkan hasil pembelajaran pada siklus II.

\section{Siklus II}

Siklus II dilaksanakan dalam pada Selasa, 30 April 2019. Dengan alokasi waktu 3 × 45 menit pada jam ke 5 - $6(10.15-11.45)$ dan jam ke 7 (12.15 - 13.00). Materi yang disampaikan adalah pelestarian lingkungan, adaptasi dan mitigasi bencana. Proses pembelajaran dilakukan oleh guru biologi dan peneliti menggunakan tiga observer sebagai pengamat dalam proses pembelajaran. Kegiatan pembelajaran siklus II dapat dijelaskan sebagai berikut:

Kegiatan yang pertama adalah pendahuluan, dilakukan selama 15 menit dari jam 10.15 - 10.30. Pada kegiatan pendahuluan semua siswa menjawab salam guru dan berdoa untuk memulai pembelajaran, meskipun masih ada satu dua yang ramai. Saat guru memberikan pertanyaan, semua siswa menjawab pertanyaan guru. Saat guru menjelaskan langkah-langkah PBL, siswa sudah fokus memperhatikan guru dan memahami langkah $P B L$ karena sudah terbiasa dari siklus I.

Tahap mengorientasi peserta didik terhadap masalah

Tahap ini dilakukan selama 10 menit dari jam 10.30 - 10.40. Pada saat guru memberikan motivasi atau rangsangan kepada siswa untuk memusatkan perhatian pada topik materi Pelestarian Lingkungan, Adaptasi dan Mitigasi Bencana, semua siswa mendengarkan motivasi yang disampaikan guru. Pada saat guru mengarahkan siswa untuk menulis poin-poin permasalahan hasil diskusi, semua siswa menuliskan poin-poin permasalahan hasil diskusi dengan kelompoknya. Materi diskusi tiap 
kelompok berbeda. Kelompok 1: Gempa 5,7 SR Guncang Seram Timur. Kelompok 2: Ratusan Hektare Padi di Polman Gagal Panen karena Kekeringan. Kelompok 3: Awal Tahun 2019 Aktivitas Gunung Berapi di Indonesia Berstatus Waspada Hingga Awas. Kelompok 4: Tsunami di Palu dan Donggala. Kelompok 5: Awal Tahun 2019 Kebakaran Lahan Muncul di Riau.

Tahap mengorganisasi siswa untuk belajar Tahap ini dilakukan selama 10 menit dari jam 10.40 - jam 10.50. Pada saat guru mengarahkan siswa untuk mencari dasar teori berdasarkan rumusan masalah, semua siswa menulis dasar teori sesuai dengan rumusan masalah dari hasil diskusi dengan kelompoknya. Karena hal ini sudah sesuai, maka ketegasan guru harus dipertahankan.

\section{Tahap mendukung kelompok investigasi}

Tahap ini dilakukan selama 15 menit dari jam 10.50 - jam 11.05. Pada saat guru membimbing siswa dalam kelompok untuk berdiskusi, semua siswa berdiskusi mencari informasi mengenai perusakan lingkungan disekitar dan mencari solusi atau usaha pelestarian lingkungan tersebut, dan menemukan cara adaptasi dan mitigasi dari bencana akibat perusakan lingkungan. Karena, hal ini sudah sesuai dengan rencana kegiatan pembelajaran, maka ketegasan guru harus dipertahankan.

Tahap mengembangkan dan menyajikan artefak dan memamerkannya

Tahap ini dilakukan selama 25 menit dari jam 11.05 - jam 11.30. Pada saat guru mengarahkan siswa untuk membuat mind mapping, semua anggota kelompok sudah tidak mengalami kesulitan dalam membuat mind mapping, karena sudah mulai terbiasa dari pertemuan siklus I. Karena, hal ini sudah sesuai dengan rencana kegiatan pembelajaran, maka ketegasan guru harus dipertahankan.

Tahap menganalisis dan mengevaluasi proses pemecahan masalah

Tahap ini dilakukan selama 45 menit dari jam (11.30 - 11.45) dilanjutkan jam (12.15 12.45). Pada saat guru mengarahkan siswa untuk memverifikasi hasil diskusi dengan literatur dan mengkonsultasikan kepada guru. Semua kelompok sudah mengkonsultasikan hasil diskusi kepada guru sebelum melakukan presentasi. Pada saat kegiatan presentasi, semua siswa aktif tanya jawab, meskipun masih ada satu dua siswa yang pasif.

\section{Kegiatan Penutup}

Kegiatan penutup dilakukan selama 15 menit dari jam 12. 45 - 13.00. Setelah siswa mengerjakan soal post test siswa sudah tenang, meskipun masih ada satu dua siswa yang ramai.

Berdasarkan hasil post test siklus II secara individu adalah jumlah siswa yang mendapatkan nilai tuntas KKM (70) sebanyak 24 siswa atau $85 \%$, dapat dilihat pada gambar 3:

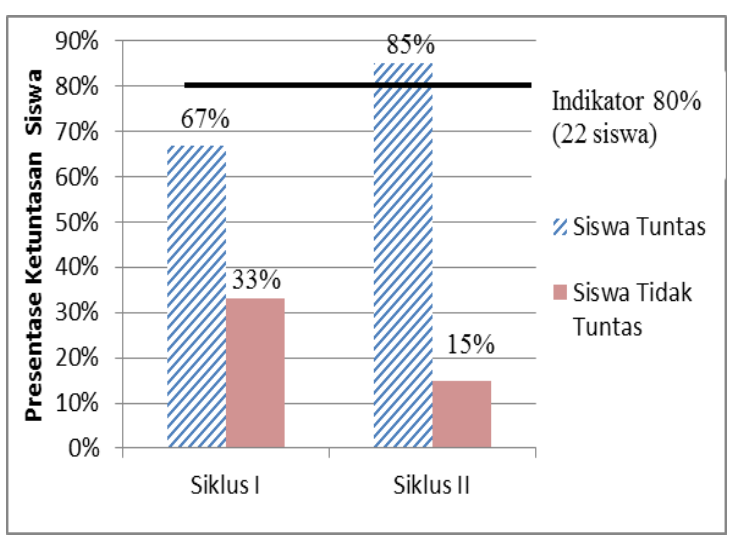

Gambar 3. Histogram Ketuntasan Siswa Siklus I

Dengan demikian dapat disimpulkan bahwa kegiatan pembelajaran siklus II dengan model PBL terjadi peningkatan. Hal-hal yang merupakan kelemahan siklus I sudah dapat teratasi pada siklus II. Guru sudah dapat menguasai kelas, sehingga semua siswa aktif dan fokus dalam belajar, meskipun masih ada 12 siswa yang ramai. Karena siklus II sudah mencapai indikator keberhasilan tindakan, sehingga penelitian dihentikan pada siklus II.

Berdasarkan data hasil penelitian terhadap hasil belajar kognitif biologi siswa dapat dilihat pada tabel 1:

Tabel 1. Hasil Belajar Kognitif Biologi

\begin{tabular}{ccc}
\hline Siklus & $\begin{array}{c}\text { Persentase } \\
\text { Ketuntasan } \\
\text { Hasil Belajar } \\
\text { Kognitif }\end{array}$ & $\begin{array}{c}\text { Indikator } \\
\text { Keberhasilan } \\
\text { Ketuntasan } \\
(80 \%)\end{array}$ \\
\hline I & $67 \%$ & Tidak Tuntas \\
II & $85 \%$ & Tuntas \\
\hline
\end{tabular}

Berdasarkan tabel 1, hasil belajar kognitif biologi mengalami peningkatan setiap siklusnya. Hasil yang diperoleh dari pembelajaran siklus I sampai dengan siklus II yaitu, siklus I sebesar 67\% (19 siswa tuntas KKM) dan siklus II 85\% (24 siswa tuntas KKM) dengan indikator ketuntasan yang ditetapkan dalam penelitian ini minimal $80 \%$ yaitu 22 dari 28 siswa. Ketika siswa bertanggung jawab dan aktif dalam kegiatan diskusi, menemukan gagasan dan solusi dalam pemecahan masalah, mereka dapat lebih mudah memahami dan 
mengetahui permasalahan yang mereka pelajari dan ketika dihadapkan dengan tes, mereka dapat mengerjakan soal tes dengan benar.

Hal ini sesuai dengan pernyataan (Supiandi \& Julung, 2016) yang menyatakan bahwa pada pembelajaran PBL, siswa dituntut untuk menanggapi, mengingat, memecahkan persoalan, menganalisis dan mengambil keputusan dalam kelompok. Hal ini dapat meningkatkan aktivitas mental siswa. Ketika aktivitas mental siswa meningkat, maka aktivitas berpikirpun juga meningkat yang pada akhirnya dapat meningkatkan kemampuan kognitif siswa sehingga berpengaruh kepada peningkatan hasil belajar kognitifnya.

Pendapat lain menyatakan bahwa PBL dapat meningkatkan hasil belajar kognitif siswa, hal ini dapat terjadi karena didukung oleh aktivitas mental siswa yang meningkat saat kegiatan pembelajaran (Hakkarainen, 2011; Machin, 2014; Rusmansyah, Yuanita, Ibrahim, Isnawati, \& Prahani, 2019; Selviani, 2019, Suryani, 2015).

Dalam penelitian yang dilakukan oleh Dayeni, Irawati \& Yennita (2017) juga menyatakan bahwa PBL dapat meningkatkan hasil belajar kognitif dalam 2 siklus. PBL dapat meningkatkan aktivitas siswa dalam mengikuti pembelajaran di kelas dan banyaknya informasi yang dapat diingat oleh siswa. Ketika partisipasi siswa meningkat, maka aktivitas berpikirpun juga meningkat yang pada akhirnya dapat meningkatkan hasil belajar kognitifnya.

Dengan demikian dari pembahasan dan data-data yang disajikan, maka dapat disimpulkan bahwa model PBL dapat meningkatkan hasil belajar siswa kelas X SMA Negeri I Bulu Kabupaten Sukoharjo. Hal ini sesuai dengan penelitian Astuti dan Junaedi (2013); Febriyanti, Herpratiwi \& Djasmi (2014); Hariatik, Suciati \& Sugiyarto (2017); Dewi, Akbari dan Nugroho (2019) tentang penerapan model Problem Based Learning dapat meningkatkan aktivitas dan hasil belajar siswa, memperbaiki dan meningkatkan kualitas proses pembelajaran, meningkatkan partisipasi siswa.

Penelitian dari Wulansari, Hanik dan Nugroho (2019) pada siswa kelas X SMA Negeri 1 Tawangsari menjelaskan bahwa model Problem Based Learning disertai mind mapping dapat meningkatkan hasil belajar biologi siswa dari segi kognitif, afektif (sikap) dan psikomotorik (ketrampilan).

Penelitian dari Purnamaningrum dan Probosari (2012) pada siswa kelas X SMA
Negeri 3 Surakarta menjelaskan bahwa penerapan model PBL dapat meningkatkan kemampaun berpikir kreatif siswa.

Selain itu penelitian dari Juanda (2016) pada siswa kelas X SMAN 19 Bandung menjelaskan bahwa penerapan model Problem Based Learning dapat meningkatkan kemampuan berpikir kritis siswa.

\section{KESIMPULAN}

Berdasarkan kegiatan penelitian tindakan kelas yang dilakukan di X IPA 3 SMA Negeri 1 Bulu Tahun Pelajaran 2018/2019, maka dapat diambil kesimpulan bahwa "Penerapan model Problem Based Learning dapat meningkatkan hasil belajar kognitif biologi siswa pada materi pembelajaran perubahan lingkungan pada kelas X IPA 3 SMA Negeri 1 Bulu Tahun Pelajaran 2018/2019"

Pada pembelajaran PBL diharapkan lebih kreatif, inovatif dan menggunakan media ajar dalam penerapan model Problem Based Learning $(P B L)$ sesuai dengan materi pelajaran, sehingga tujuan pembelajaran dapat tercapai.

\section{UCAPAN TERIMAKASIH}

Penelitian ini dapat selesai dengan baik karena bantuan dari berbagai pihak. Oleh karena itu penulis mengucapkan terima kasih kepada SMA N 1 Bulu Kabupaten Sukoharjo, yang telah banyak membantu dalam penelitian serta siswa kelas X IPA 3 SMA N 1 Bulu Kabupaten Sukoharjo Tahun Pelajaran 2018/2019.

\section{DAFTAR PUSTAKA}

Astuti, R. P., \& Junaedi, I. (2013). Peningkatan Aktivitas dan Hasil Belajar Melalui PBL Pada Siswa Kelas X SMA. Lembaran Ilmu Kependidikan, 42(2), 93-100.

Dayeni, F., Irawati, S., \& Yennita, Y. (2017). Upaya Meningkatkan Motivasi Dan Hasil Belajar Siswa Melalui Model Problem Based Learning. Pendidikan dan Pembelajaran Biologi, 1(1).

Dewi, E. H. P., Akbari, S., \& Nugroho, A. A. (2019). Peningkatan Aktivitas dan Hasil Belajar Biologi melalui Model Problem Based Learning (PBL) pada Materi Pencemaran Lingkungan Siswa Kelas X 
SMA Negeri 1 Jatisrono. Journal of Biology Learning, 1(1).

Febriyanti, R., Herpratiwi, H., \& Djasmi, S. (2015). Peningkatan Hasil Belajar Biologi dengan Menggunakan Model Pembelajaran Berbasis Masalah. Jurnal Teknologi Informasi Komunikasi Pendidikan (Old), 3(4).

Gusti, S. W., Suyanto, S., \& Ratnawati, R. (2017). Analisis Hasil Implementasi Kurikulum 2013 Dalam Aspek Sikap, Pengetahuan, Dan Keterampilan Pada Mata Pelajaran Biologi Sma Di Kabupaten Sleman Yogyakarta. Pend. Biologi-S1, 6(5), 312-322.

Hakkarainen, P. (2011). Promoting Meaningful Learning through Video ProductionSupported PBL. Interdisciplinary Journal of Problem-Based Learning, 5(1). https://doi.org/10.7771/1541-5015.1217

Hariatik, H., Suciati, S., \& Sugiyarto, S. (2017). Pembelajaran Biologi Model Problem Based Learning (PBL) Disertai Dialog Socrates (DS) Terhadap Hasil Belajar Ditinjau Dari Kemampuan Memecahkan Masalah Kelas X. Jurnal Pendidikan Biologi, 8(2), 46-51.

Juanda, J. I. H., \& Bandung, J. B. (2016). Penerapan Model PBL Pada Pelajaran Biologi Untuk Meningkatkan Kompetensi Dan Kemampuan Berpikir Kritis Siswa Kelas X. Jurnal Biologi dan Pendidikan Biologi, 1(1).

Kono, R., Mamu, H., \& Tangge, L. (2016). Pengaruh Model Problem Based Learning (PBL) Terhadap Pemahaman Konsep Biologi Dan Keterampilan Berpikir Kritis Siswa Tentang Ekosistem Dan Lingkungan Di Kelas X SMA Negeri 1 Sigi. Jurnal Sains dan Teknologi Tadulako, 5(1), 28-38.
Machin, A. (2014). Implementasi pendekatan saintifik, penanaman karakter dan konservasi pada pembelajaran materi pertumbuhan. Jurnal Pendidikan IPA Indonesia, 3(1), 28-35. https://doi.org/10.15294/jpii.v3i1.2898

Nafiah, Y. N., \& Suyanto, W. (2014). Penerapan model problem-based learning untuk meningkatkan keterampilan berpikir kritis dan hasil belajar siswa. Jurnal Pendidikan Vokasi, 4(1).

Purnamaningrum, A., \& Probosari, R. M. (2012). Peningkatan kemampuan berpikir kreatif melalui problem based learning (PBL) pada pembelajaran biologi siswa kelas X10 SMA negeri 3 surakarta tahun pelajaran 2011/2012. Pendidikan Biologi Volume 4, Nomor 3, 4(3), 39-51.

Putra, A. G. P., \& Bektiarso, S. (2017). Pengaruh Model Problem Based Learning (PBL) terhadap Hasil Belajar dan Keterampilan Proses Sains dalam Pembelajaran Fisika di SMA (Kelas X SMA Negeri 3 Jember). Jurnal Pembelajaran Fisika, 5(2), 129-134.

Rusmansyah, Yuanita, L., Ibrahim, M., Isnawati, \& Prahani, B. K. (2019). Innovative chemistry learning model: Improving the critical thinking skill and self-efficacy of pre-service chemistry teachers. Journal of Technology and Science Education, 9(1), 5976. https://doi.org/10.3926/jotse.555

Selviani, I. (2019). Pengembangan Modul Biologi Problem Based Learning Untuk Meningkatkan Kemampuan Berpikir Kritis Peserta Didik SMA. IJIS Edu: Indonesian Journal of Integrated Science Education, 1(2). https://doi.org/10.29300/ijisedu.v1i2.20 32

Sudarisman, S. (2015). Memahami hakikat dan karakteristik pembelajaran biologi dalam upaya menjawab tantangan abad 21 serta optimalisasi implementasi kurikulum 
2013. Florea: Jurnal Biologi dan Pembelajarannya, 2(1).

Sugiharto, B. (2011). Konsepsi Guru IPA Biologi SMP Se-Surakarta tentang Hakikat Biologi sebagai Sains. In Prosiding Seminar Biologi (Vol. 8, No. 1).

Supiandi, M. I., \& Julung, H. (2016). Pengaruh model problem based learning (PBL) terhadap kemampuan memecahkan masalah dan hasil belajar kognitif siswa biologi SMA. Jurnal Pendidikan Sains, 4(2), 60-64.

Suryani, I. (2015). Efektivitas Model Pembelajaran Problem Based Learning (PBL) terhadap Hasil Belajar Biologi Siswa pada materi Pencemaran
Lingkungan di kelas X SMA Negeri 2 Polewali. bionature, 16(2).

Ulfah, M., Fatmah, H., \& Herlanti, Y. (2015). Penerapan Model Pembelajaran Problem Based Learning (PBL) Dipadu Metode Student Team Achievement Division (STAD) Untuk Meningkatkan Hasil Belajar Peserta Didik Kelas X IPA 4 SMA Negeri 1 Parung Tahun Ajaran 2014/2015 Pada Konsep Perubahan Lingkungan Dan D. EDUSAINS, 7(2), 202-208.

Wulansari, B., Hanik, N. R., \& Nugroho, A. A. (2019). Penerapan Model Problem Based Learning (PBL) disertai Mind Mapping untuk Meningkatkan Hasil Belajar pada Siswa Kelas X SMA Negeri 1 Tawangsari. Journal of Biology Learning, 1(1). 